\title{
A multi-isotope and morphometric analysis to uncover ecological niche divergence in two endemic island birds from Madagascar: the Dark and Common Newtonia (Vangidae)
}

\author{
Elizabeth Yohannes ${ }^{1} \cdot$ Friederike Woog $^{2}$ (D)
}

\begin{abstract}
The common ancestry of congeneric species implies that their morphology and ecology are similar, and thus that these closely related species may experience intensified levels of competition when sympatrically distributed. Under such circumstances, selective pressure may lead to niche partitioning between and within species, with segregation achieved through variation in morphology, ecology and life history. Examining the mechanisms underlying the coexistence or segregation of congeneric species requires detailed data on aspects of their ecology such as their feeding behaviour or habitat use. Endemic island birds, such as the vangas of Madagascar, are good candidates for studying processes of niche segregation. Vangas underwent rapid speciation following the initial colonization of the island by a shared ancestor and now provide a prime example of adaptive radiation, with considerable variation in body size and shape. Four small species of Newtonia are an exception to this variation, as they show morphological overlap and partial spatial range sympatry. Here, we describe the morphology of two Newtonia species, the Common Newtonia Newtonia brunneicauda and Dark Newtonia Newtonia amphichroa, with respect to their ecology and trophic niches using a multi-isotope approach (stable isotope ratios of carbon, nitrogen and sulphur). We report evidence for adaptations involving morphological feeding traits and provide data on contrasting trophic niches between two species with a close phylogenetic relationship. We document micro-habitat niche specialization that may be due to vertical stratification within the forest. Differences in feather isotopic signatures indicate different nutrient sources and point towards microhabitat segregation that is sufficient to maintain species integrity and permit coexistence.
\end{abstract}

Keywords Stable carbon isotope ratio $\cdot$ Stable nitrogen isotope ratio $\cdot$ Stable sulphur isotope ratio $\cdot$ Adaptation . Morphology · Vangidae

\section{Zusammenfassung}

Ökologische Einnischung zweier endemischer Vogelarten in Madagaskar: Stabile Isotope und Morphometrie bei Rostbauch- und Olivbauchnewtonien (Vangidae)

Nahe verwandte Arten der gleichen Gattung sind einander in Morphologie und Ökologie oft ähnlich. Kommen sie im gleichen Gebiet vor, sollten sie sich in ihrer ökologischen Nische unterscheiden, um eine erhöhte Konkurrenz zu vermeiden. Selektive Kräfte wirken auf Variationen in Morphologie, Ökologie, Verhalten und anderen Lebensparametern innerhalb und zwischen Arten. Um die Koexistenz oder Auftrennung von nahe verwandten und sympatrisch vorkommenden Taxa zu untersuchen, sind genaue Daten zur Ökologie wie z.B. der Nahrungsökologie oder der Habitatnutzung notwendig. Endemische Inselvögel wie die Vangawürger (Vangidae) Madagaskars sind gut zur Untersuchung der Nischenaufspaltung geeignet. Nach der Erstbesiedlung Madagaskars zeigten die Vangawürger eine rasche Artbildung aus einem gemeinsamen Vorfahr und sind heute ein Paradebeispiel für adaptive Radiation. Sie zeigen eine große Variation in Körpergröße, Gestalt

Communicated by F. Bairlein.

Friederike Woog

friederike.woog@smns-bw.de

Elizabeth Yohannes

elizabeth.yohannes@uni-konstanz.de
1 Institute for Limnology, Stable Isotope Lab, University of Konstanz, Konstanz, Germany

2 Staatliches Museum für Naturkunde Stuttgart, Rosenstein 1, 70191 Stuttgart, Germany 
und Schnabelform. Vier kleine Arten der Gattung Newtonia stellen eine Ausnahme dar, da sie sich morphologisch überlappen und in Teilen ihres Verbreitungsgebiets sympatrisch vorkommen. Newtonien sind vor allem im Regenwald oft nur schwer zu beobachten, daher wurden die Tiere für die Studie in Japannetzen gefangen und nach dem Messen und Beproben wieder frei gelassen. Wir untersuchten die Morphologie von zwei Arten, die sympatrisch im Maromizaha-Regenwald im Osten Madagaskars vorkommen: der Rostbauch- (Newtonia brunneicauda) und der Olivbauchnewtonie (Newtonia amphichroa). Deren trophische Nische beschreiben wir mittels der Zusammensetzung stabiler Isotope in den Federn (Kohlenstoff $\delta^{13} \mathrm{C}$, Stickstoff $\delta^{15} \mathrm{~N}$ und Schwefel $\delta^{34} \mathrm{~S}$ ). Obwohl äußerlich zunächst ähnlich, unterschieden sich die zwei Arten in ihrer Morphologie: Olivbauchnewtonien hatten stärkere Schnäbel und längere Tarsen als Rostbauchnewtonien, was darauf hindeutet, dass sie auf etwas größere Beute spezialisiert sind und stärkere Zweige nutzen. Während beide Arten ähnliche $\delta^{15} \mathrm{~N}$ - und $\delta^{34} \mathrm{~S}$-Werte aufwiesen, zeigten Olivbauchnewtonien geringere Werte beim $\delta^{13} \mathrm{C}$. In anderen Studien zeigten Tiere, die im Wald weiter unten vorkommen, niedrigere Werte von $\delta^{13} \mathrm{C}$, was gut mit unseren Ergebnissen zusammenpasst, zudem wir die Olivbauchnewtonien im Schnitt in geringeren Netzhöhen als Rostbauchnewtonien gefangen hatten. Beide Newtonienarten scheinen sowohl durch ihre unterschiedliche Morphologie und der daraus resultierenden Unterschiede in der Art der Nahrungssuche und -aufnahme sowie durch die Unterschiede in ihrer vertikalen Habitatnutzung ausreichend getrennt, um sich im gleichen Gebiet keine Konkurrenz zu machen.

\section{Introduction}

Understanding the processes that permit species to coexist within ecological communities is an important theme in community evolution and ecology. Niche theory predicts that species can only coexist in a stable manner if intraspecific competition is stronger than interspecific competition (Grant and Price 1981; Taper and Case 1985; Chase and Leibold 2003). Following the competitive exclusion theory, if two closely related species compete for the same limited resources, one will out-compete the other (Moll and Brown 2008; Pocheville 2015), and similar species can only be fully sympatric if they avoid overlapping behaviour that might limit resource partitioning (Pulliam 2000; Bruno et al. 2003; Araújo and Guisan 2006). Such partitioning may result from different spatio-temporal use of a resource or different frequency-dependent predation patterns (Holt 1984; Holt and Lawton 1994; Chesson 2000). However, the assumptions of ecological niche theory often appear to be contradicted due to the coexistence of many closely related species (Chesson 2000; Chase and Leibold 2003; Losos 2008).

Congeneric species tend to have similar morphology and ecology, which creates a potential for intense intrageneric competition. Thus, niche theory suggests that co-occurrence of closely related species in a given community should be limited (May and Mac Arthur 1972; Holt and Lawton 1994). However, small variations dependent on morphology and life history (e.g. body size, sex, age, reproductive status or other individual variation) can lead to niche segregation between sympatric species and even within species (Lewis et al. 2005). Unravelling the means by which related taxa can co-occur is important for understanding the mechanisms and processes at work in stable ecological communities (e.g. Chesson 2000), but progress in this area is often impeded by a lack of detailed ecological data, e.g. on feeding behaviour and habitat use.
Vangas exhibited rapid speciation following the initial colonization of the island by a shared ancestor and now provide a prime example of adaptive radiation, with considerable variation in body size and shape (Yamagishi et al. 2001; Jønsson et al. 2012; Reddy et al. 2012). These morphological differences can provide useful clues to the means by which sympatric congeners achieve ecological segregation according to food niche. Vanga diets range from small to large insects and spiders, but some species also feed on fruit and vertebrates (Safford and Hawkins 2013). Molecular phylogenetic studies have reinforced the idea that these dietary choices have played an important role in the diversification of the Vangidae, but the limited field studies undertaken so far provide inadequate comparative information on their feeding ecology (Yamagishi and Eguchi 1996; Safford and Hawkins 2013) and foraging behaviour including ecomorphology (Schulenberg 2003).

An exception to the large morphological variety of the vangas described above are the four species of Newtonia. They look similar, overlap morphologically (Safford and Hawkins 2013) and show a sympatric distribution in parts of their range. Stomach content analyses have indicated that Newtonias rely on invertebrates such as insects and spiders (Goodman and Parrillo 1997; Goodman et al. 1997; Safford and Hawkins 2013). Given the large degree of overlap in reported stomach contents, and the difficulty in observing foraging behaviour of these small-sized vangids in the field, potential differences in foraging and thus trophic niche between these closely related forms are difficult to demonstrate.

Stable isotope analysis (SIA) has emerged as a powerful method for providing trophic niche information and describing inter-specific foraging diversity (Hobson 1999). Tissue stable isotope ratios of carbon $\left(\delta^{13} \mathrm{C}\right)$, nitrogen $\left(\delta^{15} \mathrm{~N}\right)$ and sulphur $\left(\delta^{34} S\right)$ obtained from individuals of sympatric species are an indirect method of exploring trophic niche. Unlike 
conventional approaches such as fecal and stomach content analysis, SIA provides integrated information about diet assimilated over an extended period of tissue synthesis (several weeks in the case of feathers). The assimilation of dietary elements by consumers is based on specific food types and on biochemical reactions that favour the lighter more abundant isotope of a particular element, resulting in an enrichment of the heavier isotope (e.g. for $\delta^{13} \mathrm{C}, \delta^{15} \mathrm{~N}$ ) in consumer tissues (Minagawa and Wada 1984; Bearhop et al. 2004).

Feather $\delta^{15} \mathrm{~N}$ values offer a reliable indication of trophic level (Hobson 1999). Carbon isotope signatures have been instructive in dietary studies of other forest-dwelling species, providing an indication of the photosynthetic pathway deployed by food plants and of vertical habitat stratification. A detailed review of $\delta^{13} \mathrm{C}$ values of large herbivorous mammals such as reindeer, red deer and roe deer from open and dense forest ecosystem environments confirmed that the isotope signature observed in plants is passed on to their consumers (Drucker et al. 2008), but the direct impacts of this on the feather isotope values of island-dwelling endemic birds have not yet been thoroughly explored.

For example, the tissues of animals foraging in open habitats are generally enriched and have higher $\delta^{13} \mathrm{C}$ values, whereas lower values represent a preference for foraging within the forest where photosynthesis induces lower $\delta^{13} \mathrm{C}$ values (heavier isotope) as a consequence of the canopy effect (Rex et al. 2011; Reuter et al. 2016). Sulphur in consumer tissues is derived from the sulphur-bearing amino acids (e.g. cysteine, methionine). $\delta^{34} \mathrm{~S}$ values are closely linked to dietary protein pathways and therefore are also useful in food web studies (Krouse et al. 1991).

In this work we examine whether microhabitat partitioning can explain the coexistence of two similar species, the Common Newtonia (Newtonia brunneicauda; CONEW) and the Dark Newtonia (Newtonia amphichroa; DANEW). Briefly, we captured birds in their breeding ranges, measured them to see if their morphology indicated differentiation and undertook multi-element SIA $\left(\delta^{13} \mathrm{C}, \delta^{15} \mathrm{~N}\right.$ and $\left.\delta^{34} \mathrm{~S}\right)$ of sampled feathers to determine whether the isotope signatures of the two species were different and thus indicated microhabitat segregation.

\section{Materials and methods}

\section{Study species}

The four extant species of Newtonia (Newtonia amphichroa, Newtonia brunneicauda, Newtonia fanovanae and Newtonia archiboldi) have only recently been reliably identified as vanga species by genetics (Jønsson et al. 2012). They show a large overlap in their morphology and occur sympatrically in parts of their range (Safford and Hawkins 2013). None of the four species migrate large distances seasonally but they do give up territoriality during the non-breeding season to join mixed-species flocks that move and forage as a group (Eguchi et al. 1993). They feed on invertebrates and gather most of their prey by gleaning foliage (Rand 1936; Langrand 1990), which is considered an ancestral way of foraging (Reddy et al. 2012).

We compare two species of Newtonia, the CONEW and DANEW. CONEWs are found in pristine to heavily disturbed primary forest including forest edges throughout the island of Madagascar, while DANEWs are restricted to more pristine rainforests of the eastern rainforest belt. CONEWs use all layers of native forest, whereas DANEWs appear to prefer dense understory (Safford and Hawkins 2013). DANEWs feed from substrates such as leaves, small branches of herbs and low shrubs on or near the ground, including the litter layer. Stomach contents analyses show that CONEWs feed on small invertebrates including spiders (Salticidae), cockroaches (Blattodea), beetles (Coleoptera: Buprestidae, Curculionidae, Scarabeidae, Anobiidae, Eumolpinae, Cleridae, Crysomelidae, Cryptocephalinae, Elateridae), true bugs (Hempiptera: leafhoppers Cicadellidae and others), Orthoptera (Gryllidae), flies (Diptera), ants and Lepidoptera (Goodman and Parrillo 1997; Goodman et al. 1997). The diet of DANEWs comprises spiders (Salticidae), beetles (Coleoptera: Crysomelidae, Curculionidae), ants, true bugs (Hemiptera) and Orthoptera (Goodman and Parrillo 1997).

Site fidelity between years (2003-2016) was very high during the breeding season (Woog and Ramanitra 2008), with $11.9 \%$ of CONEW and $19.2 \%$ DANEW recaptured the following year at the original site. Individual longevity appeared remarkable with individuals of at least 12 years of age reported for DANEW (Woog et al. 2018).

\section{Study site}

CONEWs and DANEWs occur sympatrically in the rainforest of Maromizaha, Andasibe. Maromizaha forest is located approximately $150 \mathrm{~km}$ east of the capital Antananarivo ( $\left.18^{\circ} 56^{\prime} 49^{\prime \prime} \mathrm{S}, 48^{\circ} 27^{\prime} 33^{\prime \prime} \mathrm{E}\right)$, in the commune of Andasibe, district of Moramanga (Fig. 1). It comprises an area of about 1880 ha and is part of the Ankeniheny-Zahamena forest corridor. The terrain is mountainous $(800-1200 \mathrm{~m}$ altitude), with many small streams. Capture sites were located between 1004 and $1111 \mathrm{~m}$ altitude along a gradient of habitats that differed in type and intensity of land use, and included a pristine mountain ridge, a mostly undisturbed river site, a mountain saddle, a plantation surrounded by forest and an open savannah near a quarry, with the latter being the most degraded site (Woog et al. 2006; Fig. 1). 


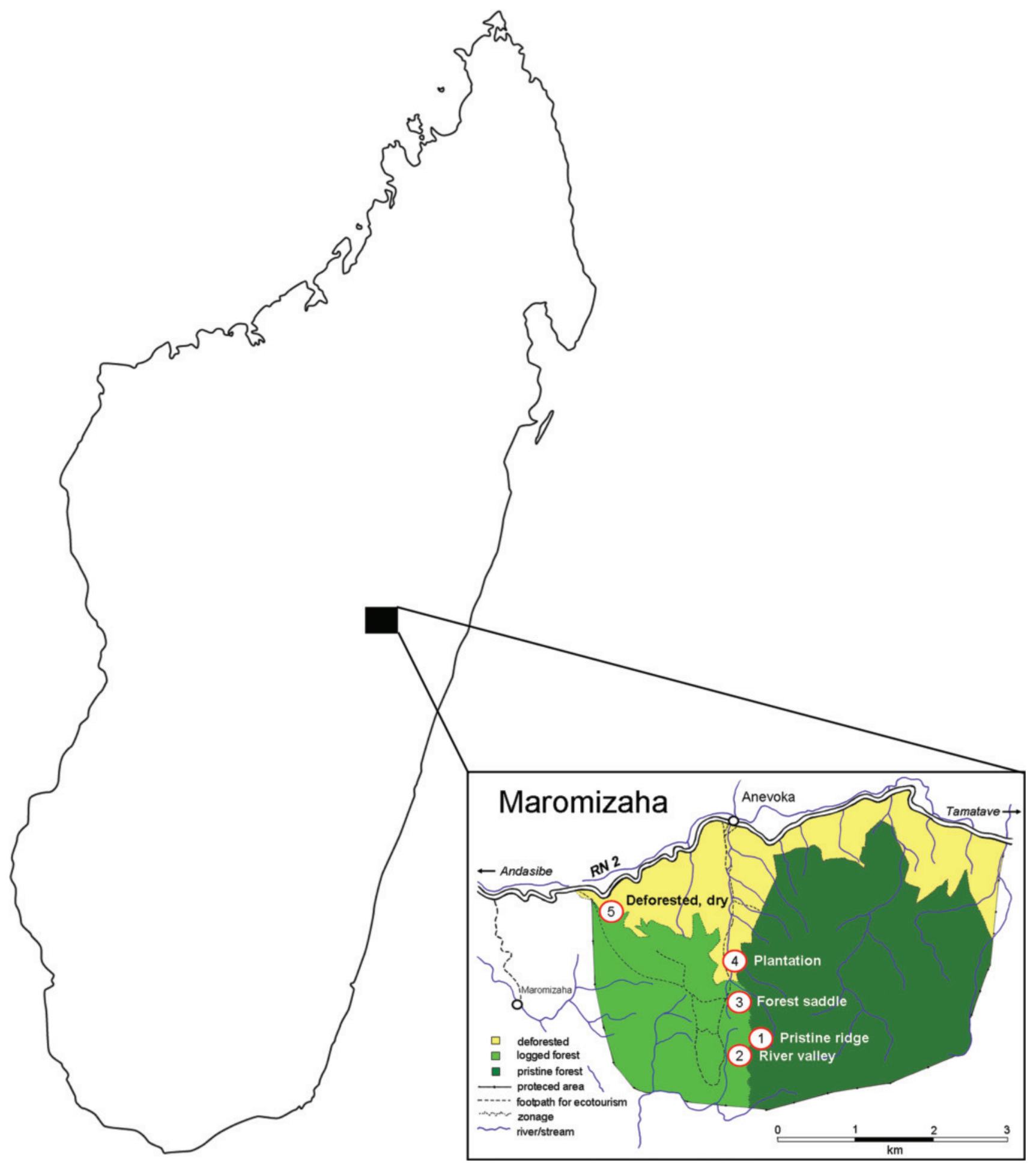

Fig. 1 Map of the five study locations in the Maromizaha forest site, Madagascar

\section{Identification and measurements}

Between 2003 and 2016, birds were captured at five sites using mist nets (66-90 net-m/site resulting in almost 400 net-m/year) for a total of 196 netting sessions comprising
1985 net-h (annually 2003-2007, 2010, 2012, 2014 and 2016). Each field season usually lasted 4 weeks/year with most data collected in November and December, coinciding with the breeding season of many bird species in the study area. Upon capture, the birds were assigned to species, sexed 
and aged according to Redfern and Clark (2001), Morris and Hawkins (1998) and Eck et al. (2011). For Newtonias, data from both sexes were lumped as the sexes did not differ in morphology, as previously reported in the literature (Safford and Hawkins 2013). Measurements were taken from all captured birds by F. W. for wing length (maximum chord), third (outermost) primary, Kipp's distance (outermost secondary to wingtip), tip of outermost primary to longest primary (DT), minimum tarsus, tail, skull length, beak length (distal edge of nostril to the tip), beak depth and beak width. All birds were weighed (Eck et al. 2011) and breeding/moulting status recorded.

From Kipp's distance and wing length we calculated indices of wing roundedness using the formula: Kipp index $=(100 \times$ Kipp's distance $) /$ wing length $)$.

High or low Kipp's index values indicate slender or more rounded wing shapes, respectively (Kipp 1959). After measuring, we sampled flank feathers for isotopic analysis. From a sub-sample of individuals, we also took a tail feather. The birds were ringed with aluminium rings before being released at their site of capture (South African ringing unit). Of 3802 birds ringed (2003-2016) only 44 were CONEWs (1.2\%) and 50 DANEWs (1.3\%), highlighting the rarity of the two species.

\section{Moult}

During our study, CONEWs were observed moulting body feathers between October and January (and probably later); this often coincided with the primary moult (19 cases out of $34,55.9 \%$ ). DANEWs moulted body feathers between November and January (and probably later), with a peak in December. This coincided with primary moult in 16 out of 37 cases $(43.3 \%)$.

\section{Capture height}

The regularly deployed mist nets had five pockets reaching from just above the ground to $2.5 \mathrm{~m}$ in total height with a 16-mm mesh size. Per site, one high net was employed that was double this height and area, reaching to $5 \mathrm{~m}$ above ground. Height classes were defined as: $1(0.1-0.50 \mathrm{~m})$, $2(0.51-1.0 \mathrm{~m}), 3(1.01-1.5 \mathrm{~m}), 4(1.51-2.0 \mathrm{~m}), 5$ $(2.0-2.50 \mathrm{~m}), 6(2.51-3.0 \mathrm{~m}), 7(3.01-3.50 \mathrm{~m}), 8$ $(3.5-4.0 \mathrm{~m}), 9(4.01-4.50 \mathrm{~m})$ and $10(4.51-5.0 \mathrm{~m})$. The height of the pocket in which each bird was captured (referred to as 'capture height') was noted.

\section{Stable isotope analyses}

Prior to analysis, sampled feathers were washed in $3: 1$ chloroform:methanol solution for $24 \mathrm{~h}$, then rinsed with distilled water and left to air dry for $24 \mathrm{~h}$. Feather keratin samples of about $0.5 \mathrm{mg}$ were then pre-weighed in tin cups, combusted using a vario MICRO cube elemental analyser (Elementar, Germany); the resultant $\mathrm{CO}_{2}, \mathrm{~N}_{2}$ and $\mathrm{SO}_{2}$ gases were introduced into a Micromass IsoPrime isotope ratio mass spectrometer (Isoprime, UK) via a continuous flow-through inlet system. Ratios of ${ }^{13} \mathrm{C} /{ }^{12} \mathrm{C},{ }^{15} \mathrm{~N} /{ }^{14} \mathrm{~N}$ and ${ }^{34} \mathrm{~S} /{ }^{32} \mathrm{~S}$ for each sample are expressed in $\delta$ notation in parts per million $(\% o)$. These values are relative to the Vienna Pee Dee belemnite standard for carbon, atmospheric $\mathrm{N}_{2}$ for nitrogen, and sulphanilamide calibrated and traceable to NBS-127 (barium sulphate, $\delta^{34} \mathrm{~S}=+20.3 \%$ ) for sulphur.

We obtained stable isotope ratios by using the equation: $\delta^{X}(\%)=1000 \times\left(R_{\text {sample }} / R_{\text {standard- } 1}\right)$, where $X$ is ${ }^{13} \mathrm{C},{ }^{15} \mathrm{~N}$ or ${ }^{34} \mathrm{~S}$ and $R$ is ${ }^{13} \mathrm{C} /{ }^{12} \mathrm{C},{ }^{15} \mathrm{~N} /{ }^{14} \mathrm{~N}$ or ${ }^{34} \mathrm{~S} /{ }^{32} \mathrm{~S}$. Internal laboratory standards indicate that our measurement errors (SD) were $\pm 0.15 \%, 0.05 \%$ and $0.05 \%$ for $\delta^{15} \mathrm{~N}, \delta^{13} \mathrm{C}$, and $\delta^{34} \mathrm{~S}$, respectively.

\section{Isotopic niche and morphometrics}

The trophic niche width of each species was assessed by calculating metrics (Layman et al. 2007) including the convex hull area (total area; TA) occupied by all individuals of each species in the $\delta^{15} \mathrm{~N}$ and $\delta^{13} \mathrm{C}$ or $\delta^{34} \mathrm{~S}$ and $\delta^{13} \mathrm{C}$ biplots and the mean distance to the $\delta^{15} \mathrm{~N}, \delta^{13} \mathrm{C}$ and $\delta^{34} \mathrm{~S}$ centroid. The centroid is the average Euclidean distance of each sample to the ellipse centroid, and serves as a measure of average trophic diversity for a species. Following Jackson et al. (2011) we used standard ellipse areas (SEA) with the Bayesian correction for small sample sizes (SEAc). This approach relies on a Bayesian method that accounts for data uncertainty and permits comparison of isotopic community metrics between groups (Jackson et al. 2011).

For each species, the ellipse centroids indicate the mean $\delta^{15} \mathrm{~N}, \delta^{13} \mathrm{C}$ and $\delta^{34} \mathrm{~S}$ values of the analysed samples. Euclidean distances between ellipse centroids (difference in centroid location) were assessed for the five vanga species. SEAc were calculated following Jackson et al. (2011) using the R package SIBER (Parnell and Jackson 2013).

\section{Statistics}

Species-specific feather $\delta^{13} \mathrm{C}, \delta^{15} \mathrm{~N}, \delta^{34} \mathrm{~S}$ and morphometric traits were normally distributed (Shapiro-Wilk test). As there were no site- or sex-specific differences in the isotope data, data of all sites and sexes were lumped by species. Species-specific differences in $\delta^{13} \mathrm{C}, \delta^{15} \mathrm{~N}$, and $\delta^{34} \mathrm{~S}$ between CONEW and DANEW were tested using Student's $t$-test. 
Element-specific differences between flank and tail feathers were analysed with paired $t$-tests using $\mathrm{R}$ software.

We opportunistically compared the stable isotope data of the two Newtonia species with three other vanga species inhabiting the same tropical forest habitat: the Blue Vanga (Cyanolanius madagascariensis), the Red-tailed Vanga (Calicalicus madagascariensis) and the Tylas Vanga (Tylas eduardi). We used ANOVA with R software to evaluate differences between feather $\delta^{13} \mathrm{C}, \delta^{15} \mathrm{~N}$ or $\delta^{34} \mathrm{~S}$ of CONEW and DANEW and the other three species.

We used one-way ANOVA followed by post hoc pairwise comparisons adjusted for multiple comparisons (Bonferroni) to detect differences in isotope values of flank feathers from CONEWs, DANEWs and Blue, Red-tailed and Tylas Vangas. We used ANOVA with R software to evaluate differences between feather $\delta^{13} \mathrm{C}, \delta^{15} \mathrm{~N}$ or $\delta^{34} \mathrm{~S}$ of CONEW and DANEW and the other three species.

Species-specific differences between DANEW and CONEW in normally distributed morphometric traits were tested using $t$-tests (equal variances, two-tailed) and capture heights using $\chi^{2}$-tests. Some individuals had missing values for certain characters, i.e. mainly due to abrasion of feathers. Multivariate analysis of external characters was therefore carried out only for individuals with complete datasets (excluding tail measurements, which were rarely taken). The measures of wing and third primary exhibited colinearity, thus only the third primary was included in the analysis. For complete datasets a multivariate analysis of variance (MANOVA) was carried out to assess overall differences in morphology of each body part adjusted for multiple comparisons (Bonferroni). Principle components analysis (PCA) was used to explore morphometric variation between the two species using JMP (Sall et al. 2012). The first two PCs were considered for subsequent analysis.

\section{Results}

\section{Habitats and capture heights}

DANEWs were captured in almost all habitats except the degraded dry savannah. Both species were most abundant on the pristine mountain ridge (Fig. 2). DANEWs were more often captured at lower net heights than CONEWs (Fig. 3; $\chi^{2}$-test: $\chi^{2}=36.54 ; d f=7 ; P<0.0001$ for a total of 116 captures including recaptures; 51 CONEWs, 65 DANEWs).

\section{Morphometric differences between CONEW and DANEW}

CONEW and DANEW showed significant morphological differences (MANOVA Wilks' $\lambda 0.075, F=54.68$,

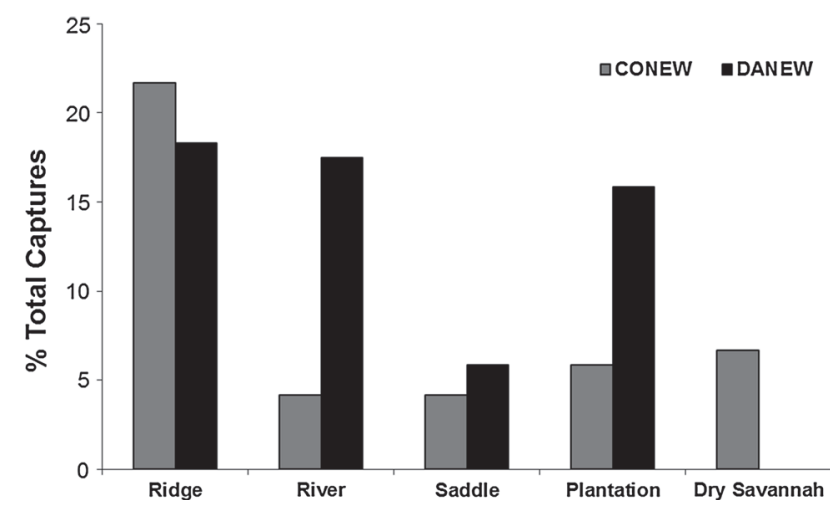

Fig. 2 Percentages of Common Newtonia (Newtonia brunneicauda; CONEW) and Dark Newtonia (Newtonia amphichroa; DANEW) caught at five different study locations

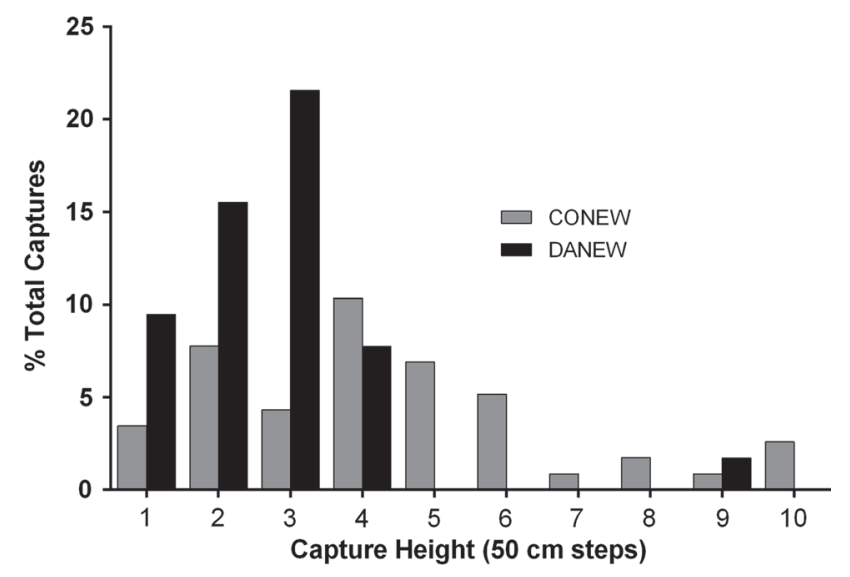

Fig. 3 Percentage of captured CONEW and DANEW from ten different tree heights. For abbreviations, see Fig. 2

$d f=1, P<0.0001)$. Table 1 shows the average values for each measurement. There were significant differences between the two Newtonias in the third primary, tarsus, skull, bill depth, bill width, Kipp's distance, weight and Kipp's index. Specifically, DANEWs had relatively larger tarsi and skulls, exhibited relatively larger bill width and depth stronger bills, had more rounded wings and were generally heavier in total body weight. No differences in wing length, tail, bill length and DT were found between the species.

PCA included the following morphological characters: third primary, skull, tarsus, bill length, bill depth, bill width, Kipp's distance and weight. PC1 explained 58.6\% of the variance observed and showed that the highest positive loading was for tarsus, weight and head measurements $(F=119.58, d f=1, P<0.0001$; Fig. 4). PC2 explained $18.5 \%$ of the variation $(F=3.17, P=0.083)$. 
Table 1 Measurements (mm) of Common Newtonia (Newtonia brunneicauda; $C O N E W)$ and Dark Newtonia (Newtonia amphichroa; DANEW) from Maromizaha rainforest, Madagascar

\begin{tabular}{|c|c|c|c|c|c|}
\hline \multirow[t]{2}{*}{ Variable (mm) } & \multicolumn{2}{|c|}{ CONEW } & \multicolumn{2}{|c|}{ DANEW } & \multirow{2}{*}{$\begin{array}{l}\text { Differences } \\
t, p, d f\end{array}$} \\
\hline & $n$ & Mean \pm SE (range) & $n$ & Mean \pm SE (range) & \\
\hline Wing & 36 & $55.9 \pm 0.26(52.0-58.5)$ & 38 & $55.7 \pm 0.27(52.5-59)$ & $0.44,0.66,71$ \\
\hline Third primary & 34 & $39.9 \pm 0.24(36.0-42.5)$ & 37 & $38.4 \pm 0.21(36-41.5)$ & $4.67,<0.0001 * * *, 66$ \\
\hline Tail & 15 & $44.4 \pm 0.49(40-48)$ & 15 & $44.3 \pm 0.59(40-47.5)$ & $0.15,0.88,26$ \\
\hline Tarsus & 37 & $19.3 \pm 0.13(17.8-21.9)$ & 42 & $22.5 \pm 0.11(20.9-23.7)$ & $-21.7,<0.0001 * * *, 76$ \\
\hline Skull & 34 & $14.2 \pm 0.10(13.0-15.5)$ & 39 & $15.2 \pm 0.08(14.1-16.2)$ & $-7.64,<0.0001 * * *, 63$ \\
\hline Bill length & 34 & $7.4 \pm 0.09(6.4-8.7)$ & 40 & $7.6 \pm 0.08(6.4-8.9)$ & $-1.15,0.253,81$ \\
\hline Bill depth & 34 & $3.0 \pm 0.03(2.6-3.3)$ & 40 & $3.2 \pm 0.03(2.8-3.5)$ & $-4.71,<0.0001 * * *, 67$ \\
\hline Bill width & 32 & $3.4 \pm 0.03(3.0-3.7)$ & 41 & $3.7 \pm 0.04(3.2-4.2)$ & $-6.90,<0.0001 * * *, 70$ \\
\hline Kipp's distance & 23 & $5.6 \pm 0.15(4.2-7.5)$ & 26 & $4.7 \pm 0.26(2-6.8)$ & $3.15,<0.003 * *, 39$ \\
\hline DT & 26 & $26.8 \pm 0.69(22.0-36.0)$ & 24 & $25.3 \pm 0.95(18-34)$ & $1.31,0.2,42$ \\
\hline Weight & 35 & $10.9 \pm 0.12(9.7-12.6)$ & 42 & $12.7 \pm 0.14(10.5-14.7)$ & $-9.89,<0.0001^{* * *}, 74$ \\
\hline Kipp's index & 22 & $10.1 \pm 0.31(7.6-14.2)$ & 22 & $8.6 \pm 0.55(3.48-12.59)$ & $2.38,<0.023^{*}, 33$ \\
\hline
\end{tabular}

$P=0.51)$ or $\delta^{34} \mathrm{~S}$ values $\left(t_{1,34}=1.47, P=0.15\right)$ between species. Flank and tail feathers exhibited no significant difference in CONEWs $\left(\delta^{13} \mathrm{C}, t_{1,5}=0.58, P=0.59\right.$; $\left.\delta^{15} \mathrm{~N}, t_{1,5}=0.64, P=0.55 ; \delta^{34} \mathrm{~S}, t_{1,5}=-174, P=0.14\right)$ or DANEWs $\left(\delta^{13} \mathrm{C}, t_{1,8}=1.92, P=0.09 ; \delta^{15} \mathrm{~N}, t_{1,8}=0.92\right.$, $P=0.39 ; \delta^{34} \mathrm{~S}, t_{1,8}=1.0, P=0.35$; Table 2 ).

For each species, the SEA contains approximately $40 \%$ of the data calculated, as an estimate of the population niche area (Table 3), but with a tendency to underestimate at small sample sizes. Correcting the SEAc and bootstrapping data $(n=10,000)$ nullifies this bias. The TA of the convex hull encompasses all values as a measure of population niche width. Figure 5 shows that CONEW has much larger TA than DANEW.

\section{Discussion}

Differences in carbon isotope signatures between the two Newtonia species appear to correlate with observed differences in morphology and habitat use. Specifically, the isotope signature of DANEWs suggests they are accessing different carbon isotope sources than CONEWs. DANEWs also exhibited greater body weight, larger tarsi and skulls, more rounded wings and larger and deeper bills than CONEWs. The general relationship between isotope values and size indicate that the latter might be a decisive factor underlying differences in feeding ecology. The
Feather $\delta^{13} \mathrm{C}$ values were significantly lower in DANEW than in CONEW $\left(t_{1,34}=6.55, P<0.0001\right)$, but there were no significant differences in $\delta^{15} \mathrm{~N}$ values $\left(t_{1,34}=0.66\right.$, bill width, Kipp's distance and weight. Open diamonds CONEW, filled circles DANEW. For abbreviations, see Fig. 2

\section{Stable isotope profiles}

Table 2 Stable isotope values for flank feathers of CONEW $(n=14)$ and DANEW $(n=22)$ from Maromizaha rainforest, Madagascar

\begin{tabular}{lcc}
\hline Isotope $(\%)$ & CONEW & DANEW \\
\hline$\delta^{13} \mathrm{C}$ & $-23.83 \pm 0.15(-25.19$ to 22.90$)$ & $-25.07 \pm 0.12(-25.19$ to 22.90$)$ \\
$\delta^{15} \mathrm{~N}$ & $6.49 \pm 0.15(5.50-7.58)$ & $6.34 \pm 0.10(5.42-7.40)$ \\
$\delta^{34} \mathrm{~S}$ & $17.73 \pm 0.18(16.76-19.30)$ & $17.47 \pm 0.08(16.9-18.51)$ \\
\hline
\end{tabular}

Values are mean \pm SE (range). For abbreviations, see Table 1 
Table 3 Isotopic niche characteristics described with quantitative species-level metrics

\begin{tabular}{|c|c|c|c|c|c|c|}
\hline \multirow[t]{2}{*}{ Species } & \multicolumn{3}{|c|}{$\delta^{13} \mathrm{C} \sim \delta^{15} \mathrm{~N}$} & \multicolumn{3}{|c|}{$\delta^{13} \mathrm{C} \sim \delta^{34} \mathrm{~S}$} \\
\hline & SEA & SEAc & TA & SEA & SEAc & TA \\
\hline DANEW & 0.81 & 0.85 & 3.11 & 0.64 & 0.68 & 2.44 \\
\hline CONEW & 1.04 & 1.12 & 3.06 & 1.18 & 1.28 & 3.28 \\
\hline Red-tailed Vanga ${ }^{a}$ & 0.52 & 0.69 & 0.59 & 0.40 & 0.53 & 0.44 \\
\hline Blue Vanga $^{\mathrm{b}}$ & 0.48 & 0.96 & 0.26 & 0.43 & 0.86 & 0.24 \\
\hline Tylas Vanga $^{c}$ & 1.69 & 1.93 & 2.50 & 1.40 & 1.60 & 2.35 \\
\hline
\end{tabular}

SEA Standard ellipse area, SEAc Bayesian SEA corrected for sample size, TA total area; for other abbreviations, see Table 1

${ }^{a}$ Calicalicus madagascariensis

${ }^{\mathrm{b}}$ Cyanolanius madagascarinus

${ }^{\mathrm{c}}$ Tylas eduardi
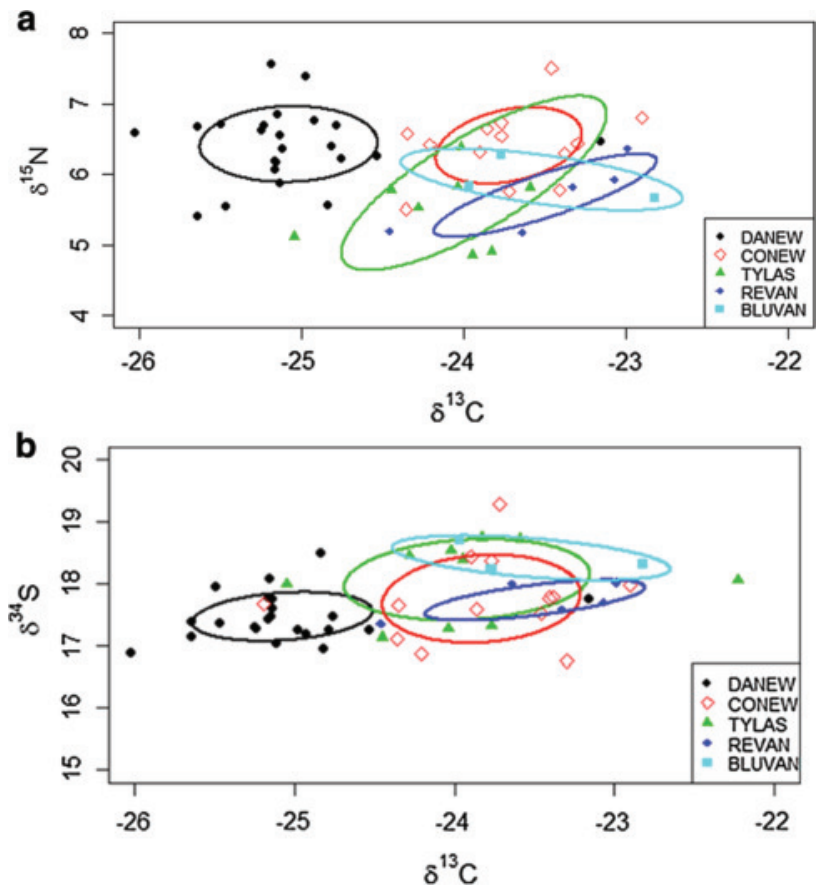

Fig. 5 Standard ellipse areas based on $\delta^{13} \mathrm{C}$ and $\delta^{15} \mathrm{~N}(\mathbf{a})$ and $\delta^{13} \mathrm{C}$ and $\delta^{34} \mathrm{~S}(\mathbf{b})$ for the five Vanga species studied in Madagascar. Each point represents the elemental values of a given sample. TYLAS Tylas Vanga, REVAN Red-tailed Vanga, BLUVAN Blue Vanga; for other abbreviations, see Fig. 2

adaptation of bill shapes suited to slightly different foraging techniques may have partitioned the ecological space between the two Newtonia species (Jønsson et al. 2012).

\section{Carbon isotopes}

The relatively low $\delta^{13} \mathrm{C}$ values found in feathers of DANEW point to species-specific microhabitat use and are most likely explained by this species' preference for intact forest and lower tree height. Compared to open landscapes, local environmental conditions under dense canopies tend to result in depleted $\delta^{13} \mathrm{C}$ values in plants (Vogel 1978; Farquhar et al. 1982; van der Merwe and Medina 1991; Bonafini et al. 2013).

The isotopic results complement our field observations. CONEWs and DANEWs occur sympatrically in a range of humid rainforest habitats, including pristine mountain ridge, river valley and mountain saddle. CONEWs were also found in an area of open and degraded secondary savannah habitat, indicating that their ecological niche is broader than that of DANEWs, which appear to be restricted to more intact and thus closed forest. The forest strata used by each species overlapped at $2 \mathrm{~m}$ above ground level, with CONEWs tending to use higher strata within the canopy than DANEWs.

\section{Nitrogen and sulphur isotopes}

Feather $\delta^{15} \mathrm{~N}$ values offer a reliable indication of trophic level (Hobson 1999). We found no significant microhabitat effect on $\delta^{15} \mathrm{~N}$ in samples from Newtonias, and similarities in feather nitrogen isotope patterns persisted at the intraspecific level between the feathers of these and the three other vanga species studied. We acknowledge that plant resources may have uniform nitrogen tissue ratios, which might propagate up the food chain from herbivorous arthropods to birds. Unfortunately, ecological and SIA data on arthropods and plants in the area are very limited. Similar nitrogen isotope values observed within our study species could indicate consumption of prey types from identical trophic niches that utilize the same elemental sources.

The pattern for feather $\delta^{34} \mathrm{~S}$ matches that observed for nitrogen isotope values in samples from CONEW and DANEW, offering strong evidence that both species target prey from the same trophic positions.

\section{Foraging plasticity}

We found no differences in the stable isotope signatures of flank and tail plumage for either of the two main study 
species, despite slightly differing moult schedules of these feather tracts. This suggests that these birds exploit almost identical nutrient resources during the replacement of both types of feather. Vanga habitat choice shows variation in vegetation types, with an isotopic gradient from $\mathrm{C}_{3}$ plants (characteristic of forest habitat) to $\mathrm{C}_{4}$ plants (typical of open savannah or drier land). Yet, in accordance with the expected lower $\delta^{13} \mathrm{C}$ ratios for plants in more humid environments (Kohn 2010), the low $\delta^{13} \mathrm{C}$ values among the five endemic vangas clearly indicate a minor dietary contribution by $\mathrm{C}_{4}$ plants. These results imply little or no foraging plasticity and no shift in trophic status during moult and feather growth. Newtonias appear to have only a limited capability to use more degraded habitats.

\section{Interspecific isotopic niche metrics}

Interspecific differences in microhabitat use and segregation might be expected to confine species to different isotopic niches. This argument appears valid for DANEW, which is segregated from CONEW and the other three vanga species by using lower strata of the forest. The latter four species are more similar in terms of their isotopic niches. Investigation of ellipse metrics gives further insights: DANEW has a relatively small TA of the convex hull encompassing all values (proxy of population niche width), consistent with the species' apparent ecological segregation using the lower strata in the forest.

We note that all studied vangas were sympatric and endemic to the Malagasy region. The much smaller convex hull area of the Blue and Red-tailed Vangas (relative to the Tylas Vanga and the two Newtonia species) reflects a narrower isotopic niche (greater microhabitat specialization), in line with previously documented trophic niche divergence. According to Losos and Ricklefs (2009), sympatry and high population densities in island species could exacerbate resource competition so that selection would favour adaptations that increase in specialization, such as morphological divergence and niche segregation. The contrasting sizes of trophic niches with partially overlapping strata (expressed as vertical stratification in our capture records) may be linked to historical segregation during early colonization of the island millions of years ago.

\section{Morphometry and food niche}

DANEWs have larger skulls, heavier beaks and larger tarsi than CONEWs. The wings of DANEWs are more rounded, which is a typical characteristic of birds inhabiting dense vegetation (Winkler and Leisler 1992; Forstmeier et al. 2001). The same trait has been found to limit natal dispersal distance in 47 British passerine bird species (Dawideit et al.
2009), which might explain the restricted range of DANEWs compared to CONEWs.

The observed differences in morphology may hint at differences in ecological niche. A heavier beak allows the capture of heavier (large-sized) prey. Brandl et al. (1994) documented a correlation between body size and prey size and the size range of dietary items taken by different bird species. Long and slender bills, for example, tend to increase dietary niche breadth. However, the same study showed that body size in birds was not necessarily related to dietary niche breadth (Brandl et al. 1994). Differences in morphology between the two Newtonia species may also point to a morphological adaptation to vegetation structure (Leisler et al. 1989), but more data are needed on this.

\section{Conclusion}

In summary, the two closely related Newtonia species DANEW and CONEW clearly have different morphology when taking into account more than the standard measurements. Their trophic niche identified by stable isotopes, however, appeared to be identical, although carbon dietary sources varied between the species. Our study suggests that the vertically structured spatial scale ranging from the lower to the higher strata of the rainforest appears to play an important ecological role in structuring communities and populations not only in bats (i.e. Reuter et al. 2016) but maybe also in birds. At a broader scale, this indicates that small-scale geography might have an impact not only on the likelihood of gene flow but also on the ecological sources of divergence (Rundle and Nosil 2005). Quantifying the role of such a 'micro' spatial scale on the population dynamics of ecological assemblages is a contemporary challenge in ecology. The habitat segregation between CONEW and DANEW should be studied also at larger spatial scales. The current study is a first attempt at exploring the ecological mechanisms that have permitted diversification in two similar vanga species from Madagascar. Future studies with a more complete set of vanga species including all four known Newtonia taxa should examine divergence within this endemic bird family to link their habitat selection, diet, morphology and genetics.

Acknowledgements We are indebted to the Malagasy authorities for granting all the relevant research and export permits and to the Groupe d'Étude et de Recherche sur les Primates de Madagascar, namely Jonah Ratsimbazafy and Rose Marie Randrianarison, for letting us work at Maromizaha. This work would not have been possible without the continued support over many years of Haja Rakotomanana and Daniel Rakotondravony at the Department of Animal Biology, University of Antananarivo. We thank Jean-Robert Lekamisi, Lova Rasolondraibe Lovahasina Tahiry, Nicola Lillich, Pia Reufsteck and all the other Malagasy and German assistants for their help in the field. We thank Wolfgang Kornberger and Claudia Greis for their assistance in the laboratory and Amy-Jane Beer (www.wildstory.co.uk) for the language 
editing. The research conducted complies with the current laws of the country in which it was performed.

\section{Compliance with ethical standards}

Conflict of Interest The authors declare that they have no conflict of interest.

Human and animal rights No animals were harmed during the study.

\section{References}

Araújo M, Guisan A (2006) Five (or so) challenges for species distribution modeling. J Biogeogr 33:1677-1688

Bearhop S, Adams CE, Waldron S, Fuller RA, MacLeod H (2004) Determining trophic niche width: a novel approach using stable isotope analysis. J Anim Ecol 73:1007-1012

Bonafini M, Pellegrini M, Ditchfield P, Pollard AM (2013) Investigation of the 'canopy effect' in the isotope ecology of temperate woodlands. J Archaeol Sci 40:3926-3935

Brandl R, Kristin A, Leisler B (1994) Dietary niche breadth in a local community of passerine birds: an analysis using phylogenetic contrasts. Oecologia 98:109-116

Bruno JF, Stachowicz JJ, Bertness MD (2003) Inclusion of facilitation into ecological theory. Trends Ecol Evol 18:119-125

Chase JM, Leibold MA (2003) Ecological niches: linking classical and contemporary approaches. University of Chicago Press, Chicago

Chesson P (2000) General theory of competitive coexistence in spatially-varying environments. Theor Popul Biol 58:211-237

Dawideit BA, Phillimore AB, Laube I, Leisler B, Böhning-Gaese K (2009) Ecomorphological predictors of natal dispersal distances in birds. J Anim Ecol 78:388-395

Drucker DG, Bridault A, Hobson KA, Szuma E, Bocherens H (2008) Can carbon $\delta^{13} \mathrm{C}$ in large herbivores reflect the canopy effect in temperate and boreal ecosystems? Evidence from modern and ancient ungulates. Palaeogeogr Palaeoclimatol Palaeoecol 266:69-82

Eck S, Fiebig J, Heynen I, Fiedler W, Nicolai B, Töpfer T, Van den Elzen R, Winkler R, Woog F (2011) Measuring birds. Deutsche Ornithologen, Radolfzell

Eguchi K, Yamagishi S, Randrianasolo V (1993) The composition and foraging behaviour of mixed species flocks of forest living birds in Madagascar. Ibis 135:91-96

Farquhar GD, O'Leary MH, Berry JA (1982) On the relationship between carbon isotope discrimination and the intercellular carbon dioxide concentration in leaves. Austral J Plant Physiol 9:121-137

Forstmeier W, Bourski OV, Leisler B (2001) Habitat choice in Phylloscopus warblers: the role of morphology, phylogeny and competition. Oecologia 128:566-576

Goodman SM, Parrillo P (1997) A study of the diets of Malagasy birds based on stomach contents. Ostrich 68:104-113

Goodman SM, Pidgeon M, Hawkins AFA, Schulenberg TS (1997) The birds of south-eastern Madagascar. Field Zool 87:1-132

Grant PR, Price TD (1981) Population variation in continuously varying traits as an ecological genetics problem. Am Zool $21: 795-811$

Hobson KA (1999) Tracing origins and migration of wildlife using stable isotopes: a review. Oecologia 120:314-326

Holt RD (1984) Spatial heterogeneity, indirect interactions, and the coexistence of prey species. Am Nat 124:377-406
Holt RA, Lawton JH (1994) The ecological consequences of shared natural enemies. Annu Rev Ecol Syst 25:495-520

Jackson AL, Inger R, Parnell AC, Bearhop S (2011) Comparing isotopic niche widths among and within communities: SIBERStable stable isotope Bayesian ellipses in R. J Anim Ecol 80:595-602

Jønsson KA, Fabre PH, Fritz SA, Etienne RS, Ricklefs RE, Jørgensen TB, Fjeldså J, Rahbek C, Ericson GP, Woog F, Pasquet E, Irestedt M (2012) Ecological and evolutionary determinants for the adaptive radiation of the Madagascan vangas. Proc Natl Acad Sci 109:6620-6625

Kipp FA (1959) Der Handflügel-Index als flugbiologisches Maß. Vogelwarte 20:77-86

Kohn MJ (2010) Carbon isotope compositions of terrestrial $\mathrm{C}_{3}$ plants as indicators of (paleo) ecology and (paleo) climate. Proc Natl Acad Sci 107:19691-19695

Krouse HR, Stewart JWB, Grinenko VA (1991) Pedosphere and biosphere. In: Krouse HR, Grinenko VA (eds) Stable isotopes: natural and anthropogenic sulphur in the environment. Wiley, Toronto, pp 267-306

Langrand O (1990) Guide to the birds of Madagascar. Yale University Press, New Haven

Layman CA, Quattrochi JP, Peyer CM, Allgeier JE (2007) Niche width collapse in a resilient top predator following ecosystem fragmentation. Ecol Lett 10:937-944

Leisler B, Ley HW, Winkler H (1989) Habitat, behaviour and morphology of Acrocephalus warblers: an integrated analysis. Ornis Scand 20:181-186

Lewis S, Schreiber EA, Daunt F, Schenk AG, Orr K, Adams A, Wanless S, Hamer CK (2005) Sex-specific foraging behaviour in tropical boobies: does size matter? Ibis 147:408-414

Losos JB (2008) Phylogenetic niche conservatism, phylogenetic signal and the relationship between phylogenetic relatedness and ecological similarity among species. Ecol Lett 11:995-1003

Losos JB, Ricklefs RE (2009) Adaptation and diversification on islands. Nature 457:830

May RM, Mac Arthur RH (1972) Niche overlap as a function of environmental variability. Proc Natl Acad Sci 69:1109-1113

Minagawa M, Wada E (1984) Stepwise enrichment of ${ }^{15} \mathrm{~N}$ along food chains: further evidence and the relation between $\delta^{15} \mathrm{~N}$ and animal age. Geochim Cosmochim Acta 48:1135-1140

Moll JD, Brown JS (2008) Competition and coexistence with multiple life history stages. Am Nat 171:839-843

Morris P, Hawkins F (1998) Birds of Madagascar: a photographic guide. Yale University Press, New Haven

Parnell A, Jackson A (2013) SIAR: stable isotope analysis in R. R package version 4.2. http://CRAN. R-project

Pocheville A (2015) The ecological niche: history and recent controversies. In: Heams T, Huneman P, Lecointre G, Silberstein M (eds) Handbook of evolutionary thinking in the sciences. Springer, Dordrecht, pp 547-586

Pulliam HR (2000) On the relationship between niche and distribution. Ecol Lett 3:349-361

Rand AL (1936) The distribution and habits of Madagascar birds: summary of the field notes of the Mission Zoologique FrancoAnglo-Americaine à Madagascar. American Museum of Natural History, New York

Reddy S, Driskell A, Rabosky D, Hackett S, Schulenberg T (2012) Diversification and the adaptive radiation of the vangas of Madagascar. Proc R Soc B 279:2011-2380

Redfern CPF, Clark JA (2001) Ringers' manual. British Trust for Ornithology

Reuter KE, Wills AR, Lee RW, Cordes EE, Sewall BJ (2016) Using stable isotopes to infer the impacts of habitat change on the diets and vertical stratification of frugivorous bats in Madagascar. PLOS ONE 11:e0153192 
Rex K, Michener R, Kunz TH, Voigt CC (2011) Vertical stratification of Neotropical Leaf-nosed Bats (Chiroptera: Phyllostomidae) revealed by stable carbon isotopes. J Trop Ecol 27:211-222

Rundle HD, Nosil P (2005) Ecological speciation. Ecol Lett 8:336-352

Safford R, Hawkins F (2013) The birds of Africa: Volume VIII: The Malagasy region: Madagascar, Seychelles, Comoros, Mascarenes, vol 8. Black, London

Sall J, Lehman A, Stephens ML, Creighton L (2012) Start statistics: a guide to statistics and data analysis using JMP. SAS Institute

Schulenberg TS (2003) The radiation of passerine birds on Madagascar. In: Goodman SM, Benstead JP (eds) The natural history of Madagascar. University of Chicago Press, Chicago, pp 1130-1134

Taper ML, Case TJ (1985) Quantitative genetic models for the coevolution of character displacement. Ecology 66:355-371

van der Merwe NJ, Medina E (1991) The canopy effect, carbon isotope ratios and food-webs in Amazonia. J Archaeol Sci 18:249-259

Vogel JC (1978) Recycling of $\mathrm{CO}_{2}$ in a forest environment. Oecol Plant 13:89-94

Winkler H, Leisler B (1992) On the ecomorphology of migrants. Ibis 134:21-28
Woog F, Ramanitra N (2008) Site fidelity of some rainforest species endemic to Madagascar. J Ornithol 147(5 Suppl. 1):275

Woog F, Ramanitra N, Rasamison S (2006) Effects of deforestation on eastern Malagasy bird communities. In: Schwitzer C, Brandt S, Ramilijaona O, Rakotomalala Razanahoera M, Ackermand D, Razakamanana T, Ganzhorn J (eds) Proceedings of the GermanMalagasy research cooperation in life and earth sciences: concept. Verlag, Berlin, pp 203-214

Woog F, Ramanitra N, Rasamison SA, Tahiry RL (2018) Longevity in some Malagasy rainforest passerines. Ostrich 89:281-286

Yamagishi S, Eguchi K (1996) Comparative foraging ecology of Madagascar vangids (Vangidae). Ibis 138:283-290

Yamagishi S, Honda M, Eguchi K, Thorstrom R (2001) Extreme endemic radiation of the Malagasy vangas (Aves: Passeriformes). J Mol Evol 53:39-46 